\title{
Demography and spatial activity of fire salamanders, Salamandra salamandra (Linnaeus, 1758), in two contrasting habitats in the Vienna Woods
}

\author{
Stephan Burgstaller, ${ }^{1,2}$, Christoph Leeb ${ }^{1,3}$, Max Ringler ${ }^{1,4,5}$, Günter Gollmann ${ }^{1}$ \\ 1 University of Vienna, Department of Evolutionary Biology, Althanstraße 14, A-1090, Vienna, Austria \\ 2 University of Natural Resources and Life Sciences, Institute of Zoology, Gregor-Mendel-Straße 33, 1180, Vienna, Austria \\ 3 Central Research Laboratories, Natural History Museum Vienna, Burgring 7, 1010, Vienna, Austria \\ 4 Division of Behavioural Ecology, Institute of Ecology and Evolution, University of Bern, Wohlenstrasse 50a, CH-3032 Hinterkappelen, Switzerland \\ 5 University of Vienna, Department of Behavioral and Cognitive Biology, Althanstraße 14, A-1090, Vienna, Austria \\ http://zoobank.org/D8088252-2AD5-4C16-9440-84BB79EF6D49 \\ Corresponding author: Stephan Burgstaller (stephan.burgstaller@gmail.com)
}

Academic editor: P. Mikulíček • Received 12 September 2020 • Accepted 15 January 2021 • Published 3 February 2021

\begin{abstract}
Understanding population dynamics is vital in amphibian conservation. To compare demography and movements, we conducted a capture-recapture study over three spring seasons in two populations of Salamandra salamandra in the Vienna Woods. The study sites differ in topography, vegetation, and the type of breeding waters. Population density in a beech forest traversed by a stream was more than twice as high as in an oak-hornbeam forest with temporary pools. Movement distances were on average higher at the latter site whereas home range estimates were similar for both sites. The sexes did not differ significantly in the observed movement patterns at either site. Annual apparent survival was mostly high $(\sim 0.85)$, but the estimate for females from the low-density site was lower $(\sim 0.60)$, indicating a higher rate of emigration or mortality.
\end{abstract}

\section{Key Words}

capture-recapture, habitat effect, home range, life history, population density, Salamandridae, site fidelity

\section{Introduction}

Amphibian populations throughout Europe are under increasing pressure from habitat loss and fragmentation (Cushman 2006; Harper et al. 2008; Arntzen et al. 2017), with Salamandra salamandra being additionally threatened by lethal fungal epidemics (Martel et al. 2013; Lötters et al. 2020). Therefore, it is important to understand amphibian population dynamics across different habitats. The capture-recapture method is widely used for analysing population dynamics and gaining valuable data for monitoring and managing conservation of threatened amphibian species (Bailey and Nichols 2006; Griffiths et al.
2010; Muths et al. 2011). The condition of populations can be described through various parameters, such as density, survival, recruitment, emigration, and immigration (Duellman and Trueb 1994), which can be estimated through modelling from capture-recapture data (Pollock 2000; Sandercock 2006). Various programs and software packages are freely available to simplify the process of model building (White and Burnham 1999; Choquet et al. 2004; Gopalaswamy et al. 2012; Efford 2020).

Previously, strong site fidelity has been described for terrestrial salamanders (Marvin 2001; Bonato and Fracasso 2003; Rebelo and Leclair 2003). However, several more recent studies suggest that populations of $S$. salamandra 
(Schmidt et al. 2007; Schulte et al. 2007; Hendrix et al. 2017) and S. infraimmaculata (Bar-David et al. 2007) can have a larger proportion of individuals with higher mobility and larger home ranges than previously thought. This indicates a high variability in movement activity and site fidelity among populations (Schmidt et al. 2014).

In the Vienna Woods, S. salamandra is common, breeding in many streams but also in ponds (Sztatecsny et al. 2014). Nonetheless, so far no data on population density or dynamics were available for the municipality of Vienna (Tiedemann 1990). In the present study we compared two populations of $S$. salamandra inhabiting contrasting habitats and therefore facing different ecological pressures and constraints: the study site Neuwaldegg extends along a stream, whereas in the Maurer Wald stagnant pools are the only available breeding sites.

Concurrent studies on these two populations have addressed aspects of genetics, morphometrics, and life history. Zutz (2012) reported similar levels of genetic diversity but genetic distinctiveness, based on variation at nine microsatellite loci. Keckeis (2013) investigated differences in larval morphology between habitats and found that larvae from the ponds in the Maurer Wald were larger than those from streams, suggesting better growth conditions in the ponds. Mayerhofer (2013) observed that adult females in the Maurer Wald were on average longer than those from Neuwaldegg but showed lower body condition index values. In the Maurer Wald additional capture-recapture data were collected outside of our study area.

Our study aimed at establishing demographic baseline data for $S$. salamandra populations in Vienna. We also wanted to explore whether differences between streamand pond-breeding populations match those reported in another study from the Kottenforst (Bonn, Germany; Hendrix et al. 2017). In this population, genetically divergent subpopulations associated with larval habitat types - ponds versus streams - differ in several life-history traits (Caspers et al. 2014; Oswald et al. 2020), including movement behaviour (Hendrix et al. 2017). The interpretation of this situation as an example of in situ adaptive divergence, possibly a first step in ecological speciation (Steinfartz et al. 2007), was recently challenged by Arntzen and van Belkom (2020), who suggested that the genetic data point to a secondary contact of differentiated lineages.

Previous studies linked sites and microhabitats with higher humidity with higher density in terrestrial salamanders (Heatwole 1962; Harper and Guynn 1999). Therefore, considering the different ecological conditions, we expected a lower population density in the Maurer Wald than in Neuwaldegg. Because the study took place in the breeding seasons, we expected a higher activity by females as reported in previous studies (Klewen 1985; Schulte 2007). Therefore, we also predicted higher recapture rates, larger movement distances and home ranges for females than for males in both habitats. Although also males may try to raise their mating chances by being more active during this time than previously thought (Manenti et al. 2017), we conjectured a higher increase in female mobility resulting from their breeding activity.

\section{Methods \\ Study species}

The fire salamander (Salamandra salamandra) is Europe's largest salamander species, reaching a total length of up to $20 \mathrm{~cm}$ and an age of up to 20 years in central Europe. In Austria only the nominate subspecies $S$. $s$. salamandra occurs. It inhabits broadleaf or mixed forests (beech, oak, and hornbeam trees predominant) with running or stagnant waters, which are utilized to deposit larvae. After metamorphosis, the animals are terrestrial and only females visit the water again to deposit their offspring (Thiesmeier 2004). Individuals have a unique dorsal pattern of yellow to orange spots and lines on a black background, which appear during metamorphosis. Only occasional slight changes of this dorsal colour pattern during ontogeny have been observed (Balogová et al. 2016), which allows reliable individual long-term identification without applying marks.

\section{Study sites}

Both study sites belong to the IUCN biosphere reserve "Vienna Woods", which is located in the Austrian states of Vienna and Lower Austria. Neuwaldegg is a site at the north-western border of Vienna and belongs to the south-eastern part of the Kierlinger Forst (WGS84, $48.249^{\circ} \mathrm{N}, 16.263^{\circ} \mathrm{E}, 389 \mathrm{~m}$ a.s.l). The forest touches the urban area of Vienna in the south-east while it extends for $\sim 10-15 \mathrm{~km}$ to the north and west. Our study plot at this site extends over an area of 7.5 ha and is located along both sides of a creek, running through a steep ravine (Fig. 1). This creek, which the salamanders use to deposit larvae, is the only water body in the study plot, and part of a network of similar creeks in the hilly Kierlinger Forst.

The second study site, the Maurer Wald, lies in the south-west of Vienna (WGS84, 48.152 ${ }^{\circ} \mathrm{N}, 16.247^{\circ} \mathrm{E}, 367$ $\mathrm{m}$ a.s.1.), between Lainzer Tiergarten, which is confined by a wall, in the north-west, a 30-100 m wide strip of open meadows and farmland, split by a road, in the south-west, and the urban area of Vienna in the east. The Maurer Wald site differs from Neuwaldegg in several aspects. The only water bodies suitable to accommodate salamander larvae are stagnant pools. The closest suitable running waters are two streams, located respectively $800 \mathrm{~m}$ south, and one kilometre west of the study plot. Further, the site's surface is flatter than in Neuwaldegg and there are few or no slopes with crevices, which often serve the salamanders for hibernation - however, the site formerly hosted military barracks and training grounds with trenches, where salamanders were found to hibernate (Leeb et al. 2013). 


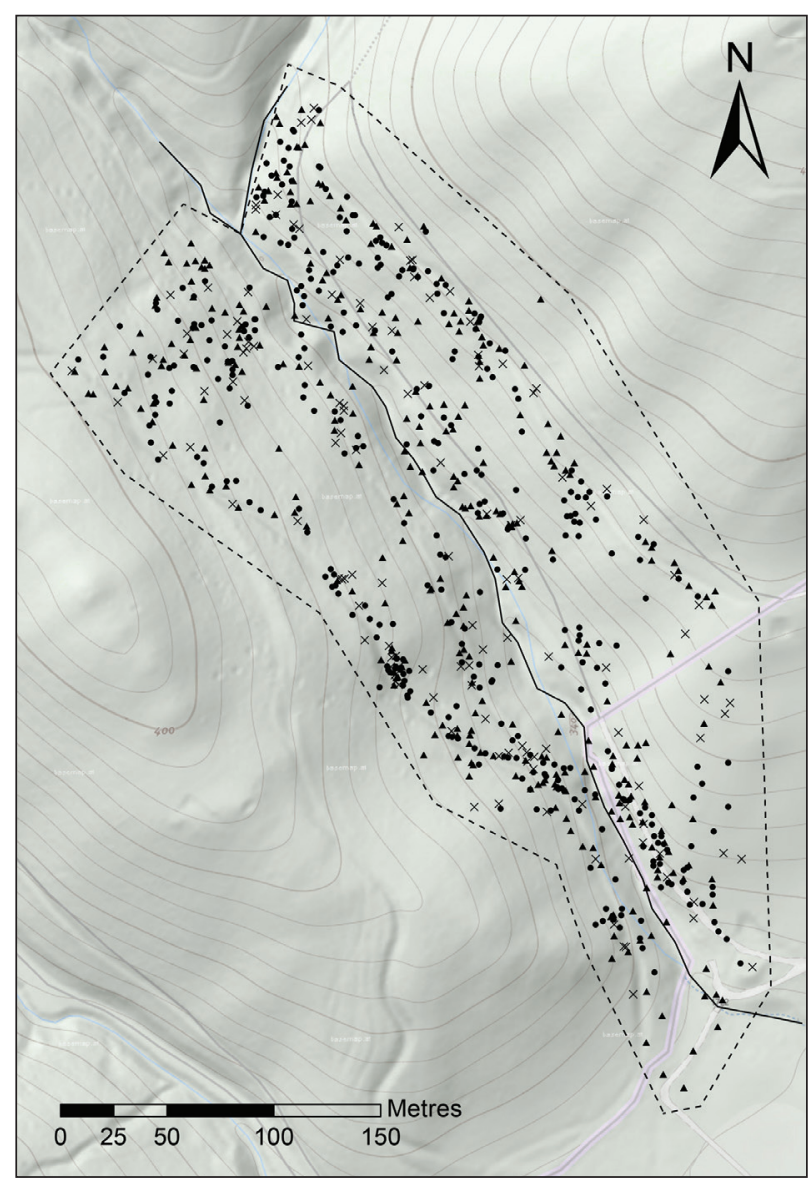

Figure 1. A map of the study site Neuwaldegg containing all capture events. Different symbols are used for females (triangle), males (filled circle) and unsexed animals (cross). The full line shows the approximate course of the creek and the dotted line the border of the sampling site. Basemaps from the WMTS server https://maps.wien.gv.at/basemap/1.0.0/WMTS-Capabilities.xml were used.

Our study plot of 5.0 ha (Fig. 2) is located in the north of the Maurer Wald; we excluded additional data from outside this area in our analysis because of non-standardized sampling. The forest in Neuwaldegg consists mainly of beech trees, whereas in the Maurer Wald oak-hornbeam forest is predominant. The latter usually grows at locations with either less precipitation, or a higher mean temperature during summer months, resulting in a higher evaporation rate (Ellenberg 1988).

\section{Data collection}

Sampling took place from 2010 to 2012 from March until June at both sampling sites for a total of 47 occasions in Neuwaldegg and 27 occasions in the Maurer Wald, mainly during rainy weather, at varying times of the day and night. In Neuwaldegg we conducted line transects along the trails on each side of the creek's ravine, whereas in the Maurer Wald we employed spatially even, opportunistic sampling to evenly search the area. We used dGPS-en-

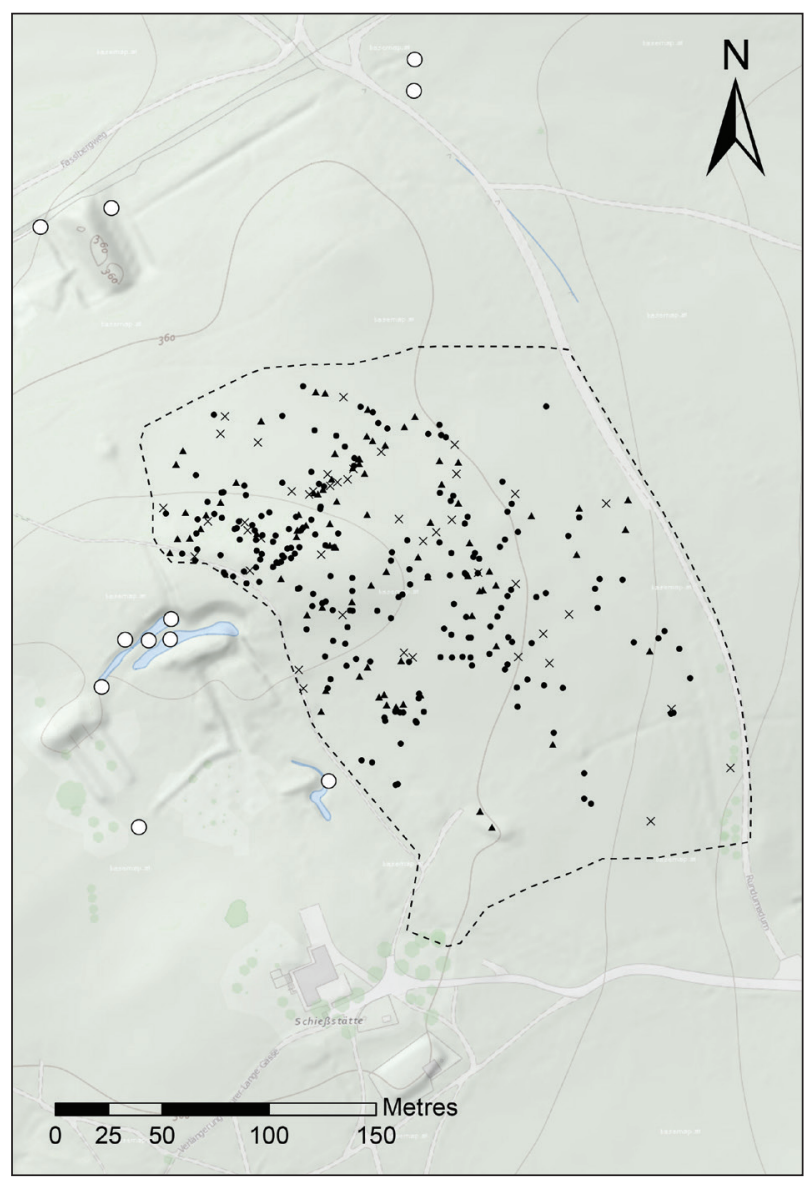

Figure 2. A map of the study site Maurer Wald containing all capture events. Different symbols are used for females (triangle), males (filled circle) and unsexed animals (cross). Breeding ponds are symbolized by empty circles and the dotted line shows the border of the sampling site. Basemaps from the WMTS server https://maps.wien.gv.at/basemap/1.0.0/WMTSCapabilities.xml were used.

abled Pocket PCs (MobileMapper 10, Ashtech/Spectra Geospatial, Westminster, CO, USA) with the mobile GIS software ArcPad 10.0 (ESRI, Redlands, CA, USA) to record the location, date, and sex of each captured animal and took pictures of the animals' dorsal pattern for individual identification. We differentiated the sexes based on the swollen cloaca of males (Nöllert and Nöllert 1992) and the general habitus (i.e. swollen belly) of females.

\section{Data preparation}

We visually identified individuals with the help of the pattern matching software WILD-ID (Bolger et al. 2012) and subsequently established individual capture histories. To process and analyse the spatial data and to visualise capture locations we used ArcMap 10.6 (ESRI, Redlands, CA, USA). To visualise home ranges for each individual captured three or more times, we constructed Minimum Convex Polygons (MCP; Powell 2000), using the Home Range Tools 2.0 Extension for ArcGIS (Rodgers et al. 2015). 


\section{Demographic analysis}

We used the software MARK (White and Burnham 1999; White 2020) to estimate apparent survival probability $\left(\varphi_{i}\right)$ and recapture probability $\left(p_{i}\right)$ with Cormack-Jolly-Seber (CJS) models (Lebreton et al. 1992). To estimate super population size $(N)$ and probability of entry $\left(p_{\text {ent }}\right)$ we used POPAN models (Schwarz and Arnason 1996) in MARK. The latter is mainly used to calculate the net population sizes $\left(N_{i}\right)$ for each sampling occasion. Sexes were represented as two distinct groups in the models.

We modelled super population size $(N)$ as constant or varying between groups and probability of entry $\left(p_{\text {ent }}\right)$ as varying through time. Apparent survival $\left(\varphi_{i}\right)$ and recapture probability $(p)$ were modelled as either constant, varying through time, varying between groups, or varying in both domains (Table 3). Models which yielded a computation error or the warning "Numerical convergence suspect" were excluded from further analysis. To test for detection heterogeneity (Gimenez et al. 2018) in the data, we used the sub-program RELEASE in MARK. The results indicated good fit for both data sets, in total and both sexes (all $\mathrm{p}>0.989)$.

To estimate the annual recapture probability $\left(p_{a}\right)$, we built two additional sets of CJS models. Capture occasions within years were pooled and treated as a single capture occasion separated by equal time intervals. We modelled $\varphi_{i}$ as constant or group dependent $(\varphi$ - constant; $\varphi_{g}$ - group-dependent) and $p_{a}$ as constant, varying through time, varying between groups or varying in both domains ( $p$ - constant, $p_{g}$ - group-dependent, $p_{t}$ - time-dependent, $p_{g^{*} t}$ - time- and group-dependent). For every combination, a model was fitted, resulting in eight models.

MARK ranks the fitted models according to their Akaike's Information Criterion corrected for small sample sizes (AICc; Anderson and Burnham 1999; Akaike 2011). A lower AICc means a better fit. The difference between a model's AICc value and the AICc value of the best fitted model is denoted as $\triangle \mathrm{AICc}$. Because of model selection uncertainty, we applied model averaging. Burnham and Anderson (2002) suggested that models with an $\triangle \mathrm{AICc}$ $>10$ lack empirical support, therefore, such models were omitted from model averaging. These calculations were carried out separately for real $\left(\varphi_{i}, p_{i}, p_{e n t}, N\right)$ and derived parameters $\left(N_{i}\right)$ with the "Model Averaging" function included in MARK.

\section{Spatial activity}

We determined distances between the two capture points farthest apart within a year for each individual $\left(d_{a}\right)$. If distances could be calculated for multiple years, we averaged them. We also measured home range size as area of the MCPs formed by all sampling locations. U-tests were used to test for differences between sampling sites, and between sexes in $d_{a}$ and home range, using the R package stats v3.6.2 (R Core Team 2020).

\section{Results}

\section{Capture data}

In Neuwaldegg, we captured 605 individual salamanders (253 m / $228 \mathrm{f})$ during 806 captures over the three years (Fig. 1). We could not determine the sex of the remaining 124 individuals. Capture events were evenly distributed over the three years. While the recapture rate within years $\left(r_{1}\right)$ was consistent across years (Table 1), recapture rates between one-year-intervals $\left(r_{2}\right)$ and the two-year-interval $\left(r_{3}\right)$ were higher than within years $\left(r_{1}\right)$. Whereas the two $r_{2}$-values were almost identical, $r_{3}$ was higher in comparison. For both sexes $r_{2}$-values were lower than the $r_{3}$-value (Table 2). Over the three years, the proportion of individuals only captured once was around $73 \%$. The proportion of individuals captured one (singleton), two (doubleton), or three or more times was very similar between sexes. Two females were captured more than four times (five and nine times, respectively) (Fig. 3).

In the Maurer Wald, we captured 217 individual salamanders (115 m / $67 \mathrm{f}$ ) during 320 captures over the three years (Fig. 2). We could not determine the sex of the remaining 35 individuals. Capture events in the Maurer Wald varied considerably between years, with 37 captures in 2010, 88 in 2011, and 195 in 2012. The $r_{1}$-value in 2010 was lower than in the two following years, in total and for both sexes, with strong differences between the sexes (Table 1). The $r_{2}$ - and $r_{3}$-values were, in general, considerably higher than $r_{l}$-values. For males they were more than 1.5 times as high as in Neuwaldegg. The female $r_{3}$-value was considerably lower than that for males (Table 2). The proportion of singletons was approximately $65 \%$, with females having over $20 \%$ more singletons than males (Fig. 3).

\section{Demographic estimations}

The best supported CJS and POPAN models for both sampling sites were time-independent apparent survival with time-dependent recapture probability. Two CJS

Table 1. Individual recaptures (absolute and relative) within each study year. Figures for the entire population, females (F) and males (M) are provided separately for each study site. $C$ refers to the number of individuals captured and released during the respective year. $c_{1}$ denotes the number of individuals, that were caught two or more times during the same year. $r_{l}$ denotes the individual recapture rate within years, it is calculated as $r_{1}=c_{1} / C$.

\begin{tabular}{lccccccc}
\hline Year & Group & \multicolumn{3}{c}{ Neuwaldegg } & \multicolumn{3}{c}{ Maurer Wald } \\
\cline { 3 - 8 } & & $\boldsymbol{C}$ & $\boldsymbol{c}_{\boldsymbol{1}}$ & $\boldsymbol{r}_{\boldsymbol{l}}(\mathbf{\%})$ & $\boldsymbol{C}$ & $\boldsymbol{c}_{\boldsymbol{1}}$ & $\boldsymbol{r}_{\boldsymbol{1}} \mathbf{( \% )}$ \\
\hline 2010 & Total & 239 & 25 & 10.5 & 34 & 3 & 8.8 \\
& $\mathrm{~F}$ & 94 & 15 & 16.0 & 10 & 0 & 0 \\
& M & 111 & 9 & 8.1 & 24 & 3 & 12.50 \\
2011 & Total & 233 & 22 & 9.4 & 74 & 12 & 16.2 \\
& F & 93 & 7 & 7.5 & 26 & 2 & 7.7 \\
& M & 98 & 13 & 13.3 & 37 & 10 & 27.0 \\
2012 & Total & 246 & 27 & 11.0 & 156 & 32 & 20.5 \\
& F & 91 & 12 & 13.2 & 42 & 3 & 7.1 \\
& M & 103 & 12 & 11.7 & 86 & 26 & 30.2 \\
\hline
\end{tabular}




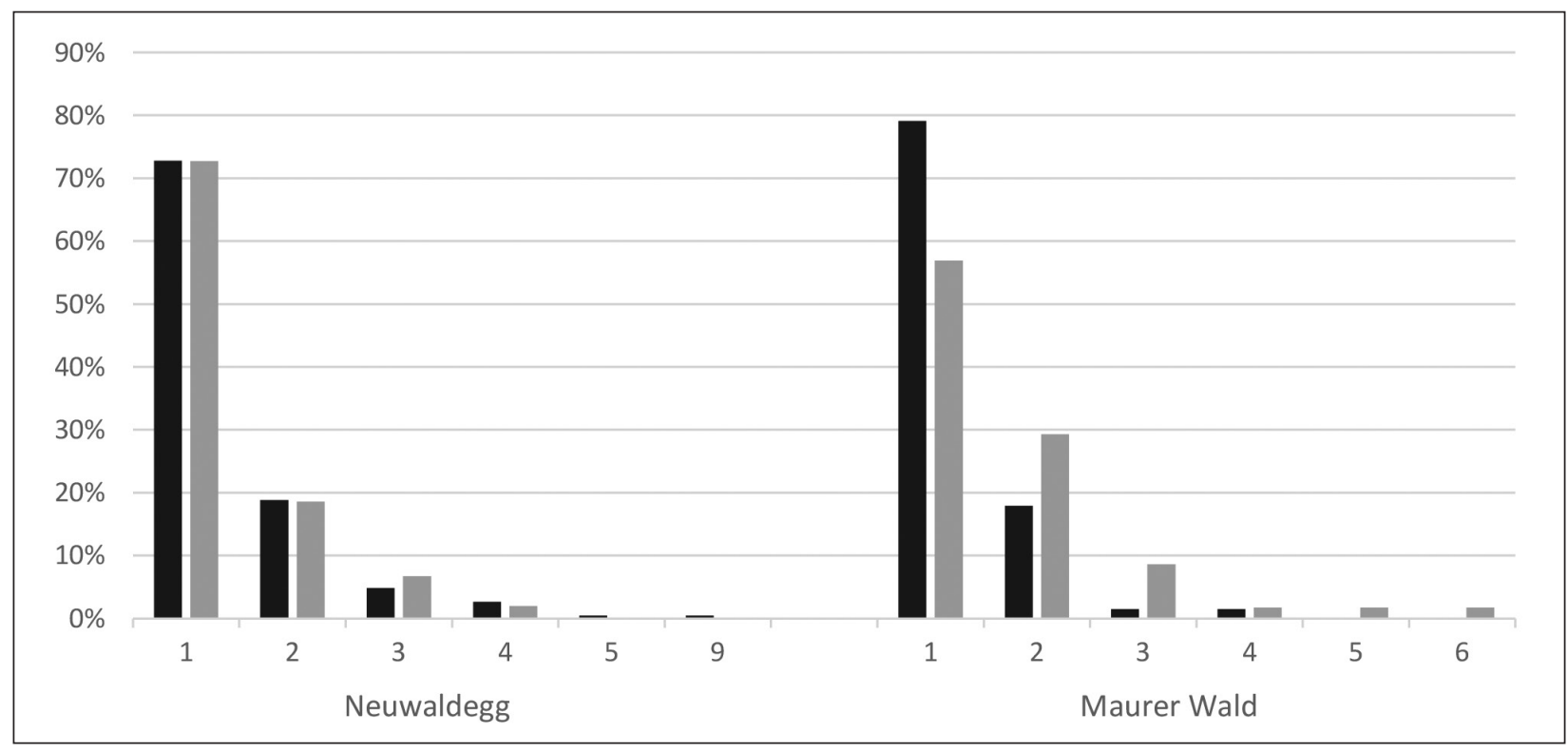

Figure 3. Relative distribution of how often individuals were captured throughout all sampling periods (2010 - 2012) in the respective sampling sites. The percentage on the y-axis corresponds to the total number of sexed individuals captured at each sampling site. Values for females and males are shown separately (females: black; males: grey). In Neuwaldegg no individuals were captured 6 to 8 times.

models and four POPAN models had a high enough support to be included into model averaging. The data from both sampling sites supported the same models, although the specific POPAN models were ranked differently for each site. These models differed from each other only by whether $\varphi_{i}$ and $N$ were modelled as group-dependent or not. Group-dependency in general had relatively little effect on the model's support (Table 3).

\section{Apparent survival}

Model-averaged estimates for monthly apparent survival $\left(\varphi_{m}\right)$ between sampling sites and groups were consistent except for females from the Maurer Wald. While the CJS

Table 2. Individual recaptures (absolute and relative) between years. Figures for the entire population, females (F) and males (M) are provided separately for each study site. $C$ refers to the number of individuals captured and released during the former of two compared years. $c_{2,3}$ denotes the number of individuals, that were released in the former and recaptured in the latter of two compared years. $r_{2}$ denotes the recapture rate between oneyear intervals and $r_{3}$ for the two-year interval. They are calculated as $r_{2,3}=c_{2,3} / C$.

\begin{tabular}{lccccccc}
\hline Interval & Group & \multicolumn{3}{c}{ Neuwaldegg } & \multicolumn{3}{c}{ Maurer Wald } \\
\cline { 3 - 8 } & & $\boldsymbol{C}$ & $\boldsymbol{c}_{2}$ & $\boldsymbol{r}_{\mathbf{2}}(\mathbf{\%})$ & $\boldsymbol{C}$ & $\boldsymbol{c}_{2}$ & $\boldsymbol{r}_{\mathbf{2}}(\mathbf{\%})$ \\
\hline $2010-$ & Total & 239 & 39 & 16.3 & 34 & 10 & 29.4 \\
2011 & $\mathrm{~F}$ & 94 & 17 & 18.1 & 10 & 2 & 20.0 \\
& $\mathrm{M}$ & 111 & 22 & 19.8 & 24 & 8 & 33.3 \\
$2011-$ & Total & 233 & 38 & 16.3 & 74 & 29 & 39.2 \\
2012 & $\mathrm{~F}$ & 93 & 19 & 20.4 & 26 & 8 & 30.8 \\
& $\mathrm{M}$ & 98 & 16 & 16.3 & 37 & 17 & 46.0 \\
& & $\boldsymbol{C}$ & $\boldsymbol{c}_{3}$ & $\boldsymbol{r}_{\mathbf{3}}(\mathbf{\%})$ & $\boldsymbol{C}$ & $\boldsymbol{c}_{3}$ & $\boldsymbol{r}_{3}(\mathbf{\%})$ \\
$2010-$ & Total & 239 & 49 & 20.5 & 34 & 11 & 32.4 \\
2012 & $\mathrm{~F}$ & 94 & 21 & 22.3 & 10 & 1 & 10.0 \\
& $\mathrm{M}$ & 111 & 27 & 24.3 & 24 & 10 & 41.7 \\
\hline
\end{tabular}

model estimates for three of four groups had a relatively narrow range of 0.989 to 0.991 , for the fourth group (females from the Maurer Wald), $\varphi_{m}$ was estimated to be only 0.958 . These estimates translate to annual apparent survival $\left(\varphi_{a}\right)$ of 0.873 to 0.895 and 0.601 , respectively. Estimates from the POPAN models were generally a little lower but showed a similar pattern (Table 4).

Table 3. Overview of the best supported CJS and POPAN models. Data from both sampling sites are included. Model labels consist of the involved parameters and their dependencies as subscripts. These parameters are apparent $\operatorname{survival}\left(\varphi_{i}\right)$, recapture probability $\left(p_{i}\right)$ and super population size $(N)$. Their subscripts designate the parameters as either constant (.), time-dependent $(\mathrm{t}$; different at each capture occasion) or group-dependent ( $\mathrm{g}$; different values for each sex). The probability of entry $\left(p_{e n t}\right)$ was always modelled in the same manner (time-dependent) and therefore not included in the label. The rest of the table entries are the difference in the AICc value between the respective model and the best supported model ( $\triangle \mathrm{AICc})$, the AICc weight (w), the number of estimated parameters $(\mathrm{K})$ and the model's deviance. Models were fitted for each model structure and sampling site separately. Models with an $\triangle \mathrm{AICc}>10$ did not contribute to model averaging and were omitted from the table.

\begin{tabular}{|c|c|c|c|c|c|c|}
\hline Model structure & Sampling site & Model & $\triangle \mathrm{AICc}$ & $\mathbf{w}$ & $\mathbf{K}$ & Deviance \\
\hline \multirow[t]{4}{*}{ CJS } & \multirow[t]{2}{*}{$\mathrm{NE}$} & $\varphi ., p_{t}$ & 0.00 & 0.720 & 47 & 983.42 \\
\hline & & $\varphi_{g}, p_{t}$ & 1.89 & 0.280 & 48 & 982.99 \\
\hline & \multirow[t]{2}{*}{ MW } & $\varphi_{g}, p_{t}$ & 0.00 & 0.759 & 28 & 391.33 \\
\hline & & $\varphi ., p_{t}$ & 2.30 & 0.241 & 27 & 396.11 \\
\hline \multirow[t]{8}{*}{ POPAN } & \multirow[t]{4}{*}{ NE } & $\varphi_{.}, p_{t}, N$. & 0.00 & 0.499 & 54 & -1724.14 \\
\hline & & $\varphi_{g}, p_{t}, N$. & 1.62 & 0.222 & 55 & -1724.89 \\
\hline & & $\varphi ., p_{t}, N_{g}$ & 1.76 & 0.227 & 55 & -1724.75 \\
\hline & & $\varphi_{g}, p_{t}, N_{g}$ & 3.88 & 0.072 & 56 & -1725.02 \\
\hline & \multirow[t]{4}{*}{ MW } & $\varphi_{g}, p_{t}, N$. & 0.00 & 0.740 & 35 & -411.92 \\
\hline & & $\varphi_{g}, p_{t}, N_{g}$ & 2.49 & 0.213 & 36 & -412.08 \\
\hline & & $\varphi ., p_{t}, N$. & 6.09 & 0.035 & 34 & -403.21 \\
\hline & & $\varphi ., p_{t}, N_{g}$ & 8.26 & 0.012 & 37 & -408.97 \\
\hline
\end{tabular}


Table 4. Model averaged estimates for monthly apparent survival $\left(\varphi_{m}\right)$ and initial population size $(N)$. Estimates for females (F) and males (M), from both sampling sites, are provided separately. Annual apparent survival $\left(\varphi_{a}\right)$ is calculated as $\varphi_{m}{ }^{12} \cdot \varphi_{m}$ is estimated using both CJS and POPAN models.

\begin{tabular}{|c|c|c|c|c|c|c|c|c|c|c|c|}
\hline \multirow[t]{2}{*}{ Site } & \multirow[t]{2}{*}{ Sex } & \multirow{2}{*}{$\begin{array}{c}\text { Model } \\
\text { structure }\end{array}$} & \multicolumn{3}{|c|}{$\varphi_{m}$} & \multirow{2}{*}{\multicolumn{2}{|c|}{$\varphi_{a}$}} & \multicolumn{4}{|c|}{$N$} \\
\hline & & & Est. & SE & LCI & & & Est. & SE & LCI & UCI \\
\hline \multirow[t]{4}{*}{$\mathrm{NE}$} & $\mathrm{F}$ & CJS & 0.989 & 0.009 & 0.949 & 0.998 & 0.876 & - & - & - & - \\
\hline & & POPAN & 0.987 & 0.008 & 0.956 & 0.996 & 0.850 & 492 & 41.49 & 410.58 & 573.24 \\
\hline & M & CJS & 0.991 & 0.009 & 0.974 & 1.008 & 0.895 & - & - & - & - \\
\hline & & POPAN & 0.988 & 0.008 & 0.956 & 0.997 & 0.863 & 506 & 45.90 & 415.64 & 595.55 \\
\hline \multirow[t]{4}{*}{ MW } & F & CJS & 0.958 & 0.022 & 0.886 & 0.986 & 0.601 & - & - & - & - \\
\hline & & POPAN & 0.953 & 0.019 & 0.900 & 0.979 & 0.562 & 141 & 17.09 & 107.30 & 174.31 \\
\hline & M & CJS & 0.989 & 0.011 & 0.930 & 0.998 & 0.873 & - & - & - & - \\
\hline & & POPAN & 0.988 & 0.009 & 0.944 & 0.998 & 0.867 & 154 & 28.06 & 99.12 & 209.12 \\
\hline
\end{tabular}

\section{Recapture probability}

Recapture probability $\left(p_{i}\right)$ was always modelled as only time-dependent. Therefore, the model averaged estimates were the same for both groups but were different for each capture occasion. The estimates strongly differed between capture occasions and correlated with the number of animals captured on the respective occasions in both CJS and POPAN models. Up to the eleventh capture occasion the confidence intervals for these estimates were quite large and therefore the estimates yield no meaningful results. They were excluded from further analysis and discussion. The CJS models yielded no estimates for three occasions for the Neuwaldegg data set and for seven occasions for the Maurer Wald data set. For the Neuwaldegg data set, the estimates ranged from 0.003 to 0.087 for CJS and from 0.001 to 0.086 for POPAN models, whereas they ranged from 0.007 to 0.210 for CJS and from 0.004 to 0.225 for POPAN models for the Maurer Wald data set.

The estimates for annual recapture probabilities $\left(p_{a}\right)$ for the Maurer Wald were around twice as high as the estimates for Neuwaldegg for both sexes (Table 5). Differences between years and sexes were low.

\section{Population size $\left(N, N_{i}\right)$ and density}

We estimated both the super population size $(N)$ and the net population sizes $\left(N_{i}\right)$ for each capture occasion using POPAN models. Model averaging yielded super population estimates of $492\left(65 \mathrm{ha}^{-1}\right)$ females and $506\left(67 \mathrm{ha}^{-1}\right)$ males for the sampling site in Neuwaldegg. For the Maurer Wald $141\left(28 \mathrm{ha}^{-1}\right)$ females and $154\left(31 \mathrm{ha}^{-1}\right)$ males were estimated (Table 4).

Table 5. Model averaged estimates (CJS models) for annual recapture probability $\left(p_{a}\right)$. Estimates for females $(\mathrm{F})$ and males (M), from both sampling sites, are provided separately.

\begin{tabular}{lccccccc}
\hline Year & Sex & \multicolumn{3}{c}{ Neuwaldegg } & \multicolumn{3}{c}{ Maurer Wald } \\
\cline { 3 - 8 } & & Estimate & LCI & UCI & Estimate & LCI & UCI \\
\hline 2011 & F & 0.194 & 0.145 & 0.253 & 0.375 & 0.144 & 0.682 \\
& M & 0.195 & 0.148 & 0.254 & 0.423 & 0.222 & 0.652 \\
2012 & F & 0.195 & 0.155 & 0.243 & 0.411 & 0.145 & 0.742 \\
& M & 0.196 & 0.159 & 0.240 & 0.461 & 0.227 & 0.713 \\
\hline
\end{tabular}

Net population size estimates $\left(N_{i}\right)$ for Neuwaldegg ranged from $349\left(46 \mathrm{ha}^{-1}\right)$ to $444\left(59 \mathrm{ha}^{-1}\right)$ for females and from $382\left(51 \mathrm{ha}^{-1}\right)$ to $473\left(63 \mathrm{ha}^{-1}\right)$ for males. The estimates decreased over time for both sexes. For the Maurer Wald estimates ranged from $42\left(8 \mathrm{ha}^{-1}\right)$ to 87 (18 $\left.\mathrm{ha}^{-1}\right)$ for females and from $60\left(12 \mathrm{ha}^{-1}\right)$ to $170\left(34 \mathrm{ha}^{-1}\right)$ for males. Here, the estimates increased over time for both sexes. The estimates showed no recurring patterns over the annual sampling periods. The large $95 \%$ CI range for the first eight occasions from Neuwaldegg made the estimates highly uncertain and therefore they were removed from further analysis and discussion (Fig. 4).

\section{Spatial activity}

The total maximum distances within years $\left(d_{a}\right)$ of females (median: $23 \mathrm{~m}$; range: 5-224 m) and males (median: 23 $\mathrm{m}$; range: 1-207 m) from Neuwaldegg showed no significant differences $(U=469 ; p=0.258)$ (Fig. 5). Also, for the Maurer Wald those distances (Fig. 5) showed no significant differences $(U=85 ; p=0.862)$ between females (median: $33 \mathrm{~m}$; range: 10-72 $\mathrm{m}$ ) and males (median: 32 $\mathrm{m}$; range: 6-99 m). In the Maurer Wald only five $d$-values could be calculated for females. The $d$-values from the Maurer Wald (median: $33 \mathrm{~m}$; range: 6-99 m) were significantly larger than those from Neuwaldegg (median: $23 \mathrm{~m}$; range: $1-224 \mathrm{~m})(\mathrm{U}=1061 ; \mathrm{p}=0.048)$.

In Neuwaldegg, no significant differences of Minimum Convex Polygons between females (median: 112 $\mathrm{m}^{2}$; range: $21-573 \mathrm{~m}^{2}$ ) and males (median: $152 \mathrm{~m}^{2}$; range: 4-1012 $\left.\mathrm{m}^{2}\right)$ were found $(\mathrm{U}=207 ; \mathrm{p}=0.969)$. For the Maurer Wald, due to the small sample size for female home ranges $(n=2)$, it was not possible to test home ranges for significance between females (median: 87 $\mathrm{m}^{2}$; range: $86-89 \mathrm{~m}^{2}$ ) and males (median: $136 \mathrm{~m}^{2}$; range: $8-2329 \mathrm{~m}^{2}$ ). Total home ranges for Neuwaldegg ranged from 4 to $1012 \mathrm{~m}^{2}$ (median: $117 \mathrm{~m}^{2}$ ) while they ranged from 8 to $2329 \mathrm{~m}^{2}$ (median: $113 \mathrm{~m}^{2}$ ) in the Maurer Wald (Fig. 6), and no significant differences were found between the sites $(U=389 ; p=1)$. Home ranges and maximum distances across all years are shown in Figs $7,8$.

\section{Discussion}

Contrary to our expectation the recapture rates of females were not consistently higher in Neuwaldegg and even were clearly lower in the Maurer Wald compared to the recapture rates of males. The fact that total recapture rates within years $\left(r_{l}\right)$ were universally lower than total recapture rates between years $\left(r_{2}, r_{3}\right)$, in both Neuwaldegg and the Maurer Wald, hints to a seasonal site fidelity in both sites. At least for females this is consistent with the proximity of their respective breeding waters to the sampling areas. Manenti et al. (2017) observed that also male fire salamanders move closer to the breeding sites during the breeding season, presumably to increase their chances to find a mate. This 


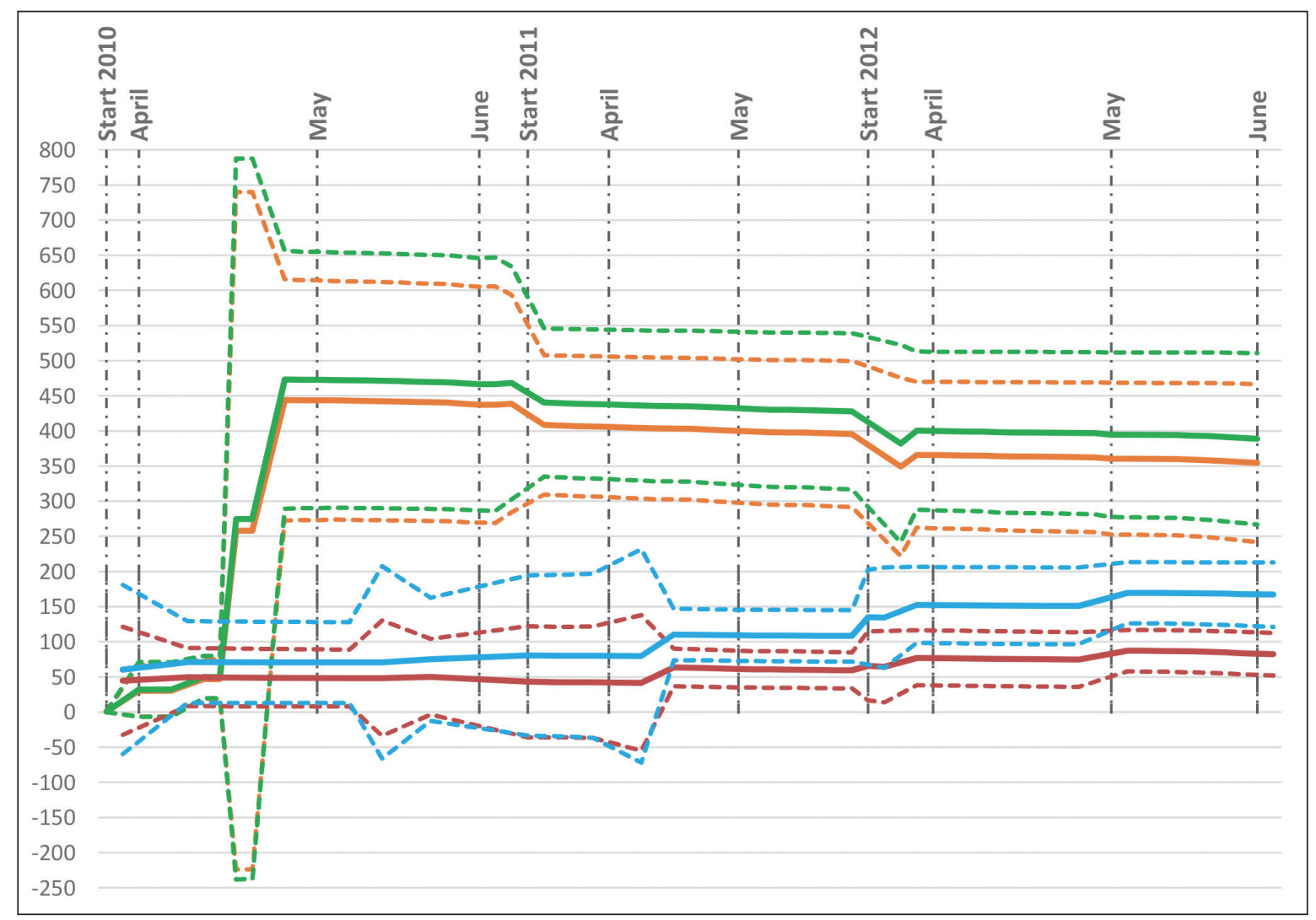

Figure 4. Net population sizes $\left(N_{i}\right)$ for each capture occasion. Separate graphs are provided for Neuwaldegg and the Maurer Wald and sexes respectively. Neuwaldegg: green (males), orange (females); Maurer Wald: blue (males), red (females); dashed lines denote the lower (LCI) and upper (UCI) bound of the estimates 95\%-CI. Dashed vertical lines denote the first capture occasion (CO) of a year or the first $\mathrm{CO}$ of a month.

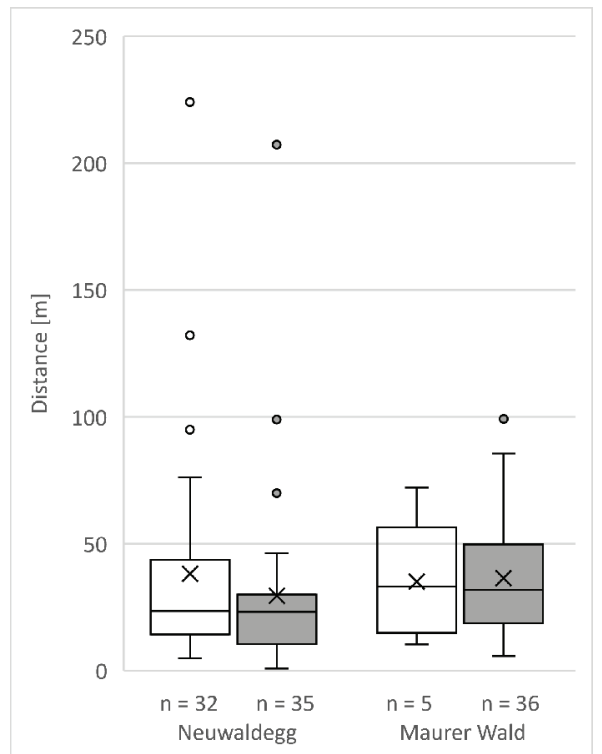

Figure 5. Annual maximum movement distances for each sampling site and sex (females: white; males: grey). Crosses symbolize the mean and horizontal lines within the boxes the median values. The box lies between the lower quartile $\left(25^{\text {th }}\right.$ percentile $)$ and the upper quartile $\left(75^{\text {th }}\right.$ percentile). Whiskers denote the minimum and maximum values, not counting outliers. Outliers are values that are more than $1.5 * \mathrm{IQR}$ (interquartile range) higher than the upper or less than the lower quartile and are denoted as circles.

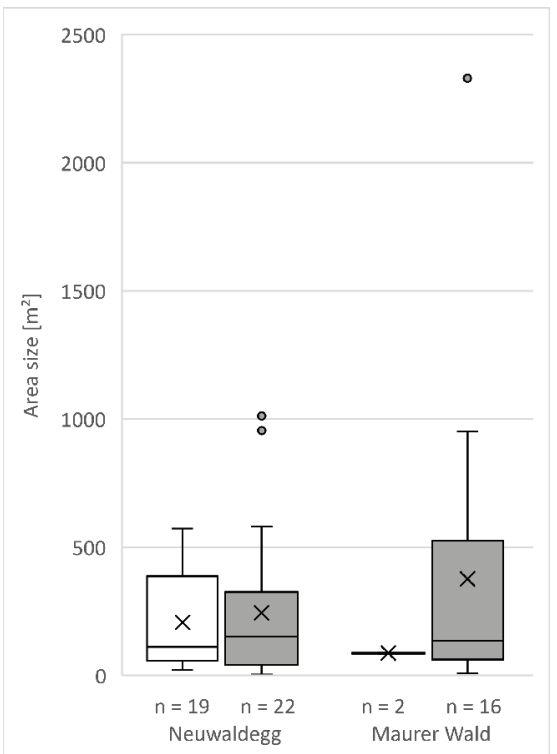

Figure 6. Home range sizes for each sampling site and sex (females: white; males: grey). Crosses symbolize the mean and horizontal lines within the boxes, the median values. The box lies between the lower quartile $\left(25^{\text {th }}\right.$ percentile) and the upper quartile $\left(75^{\text {th }}\right.$ percentile). Whiskers denote the minimum and maximum values, not counting outliers. Outliers are values that are more than $1.5^{*} \mathrm{IQR}$ (interquartile range) higher than the upper or less than the lower quartile and are denoted as circles. 


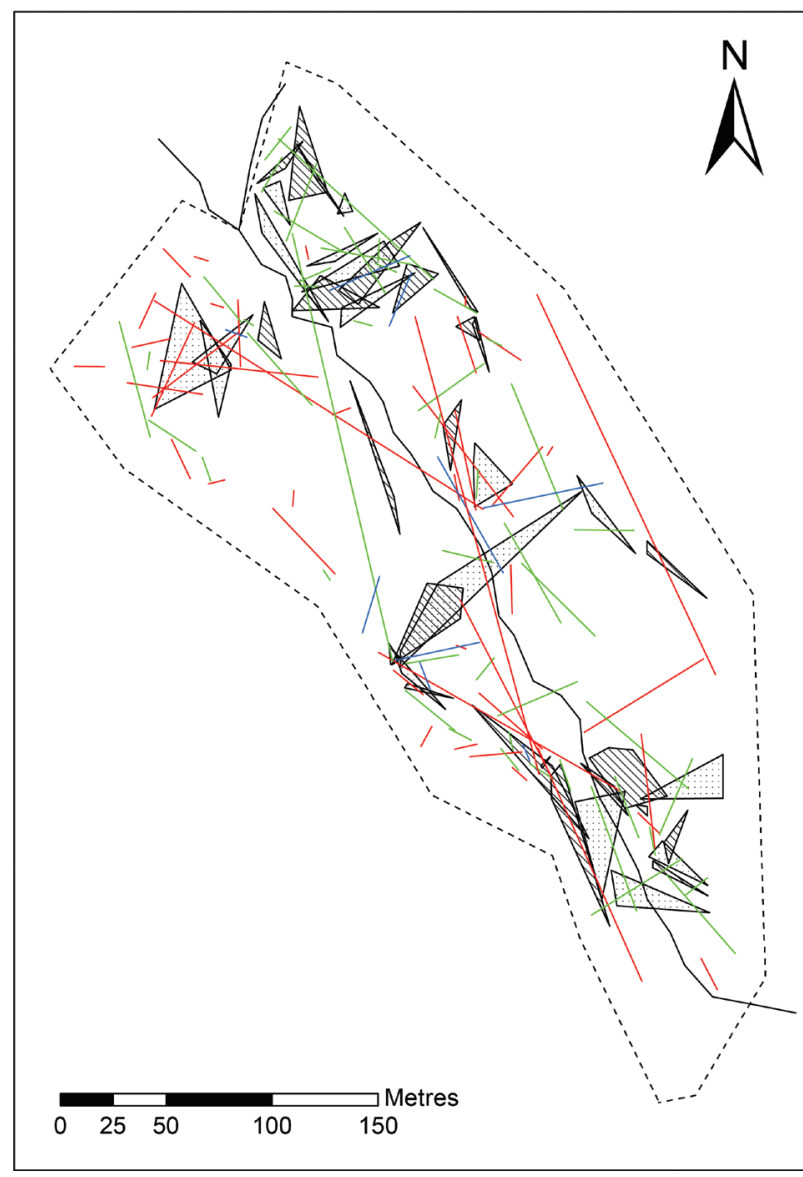

Figure 7. Home ranges and individual movements over all sampling periods in Neuwaldegg. The home range of individuals, captured three times or more, is represented by MCPs (Females: diagonal lines; Males: dotted). Distances between capture locations of individuals recaptured only once are represented by coloured straight lines (Females: red; Males: green; Unsexed: blue).

behaviour might increase the population density near the breeding waters without changing the sex ratio.

We assume that a portion of individuals in Neuwaldegg might skip reproduction in some years, due to the demanding migration. In Neuwaldegg the recapture rate in the two-year-interval was higher compared to the rates of the one-year intervals. This fluctuation was not seen in the Maurer Wald. Individuals, especially females, of various other long-lived amphibian species occasionally skip years of reproduction because of high reproductive investment or unfavourable environmental conditions (Bull and Shine 1979; Cayuela et al. 2014). Consequently, during these years, they have a reduced probability of being detected. To come to conclusive results in this regard, data over a longer time span would be needed.

Apparent survival estimates for both sexes from Neuwaldegg and males from the Maurer Wald were rather similar and consistent with estimates from other studies (Schmidt et al. 2005; Schmidt et al. 2014; Balogová et al. 2017), whereas for females from the Maurer Wald estimates of $\varphi_{a}$ were considerably lower (Table 4). This low-

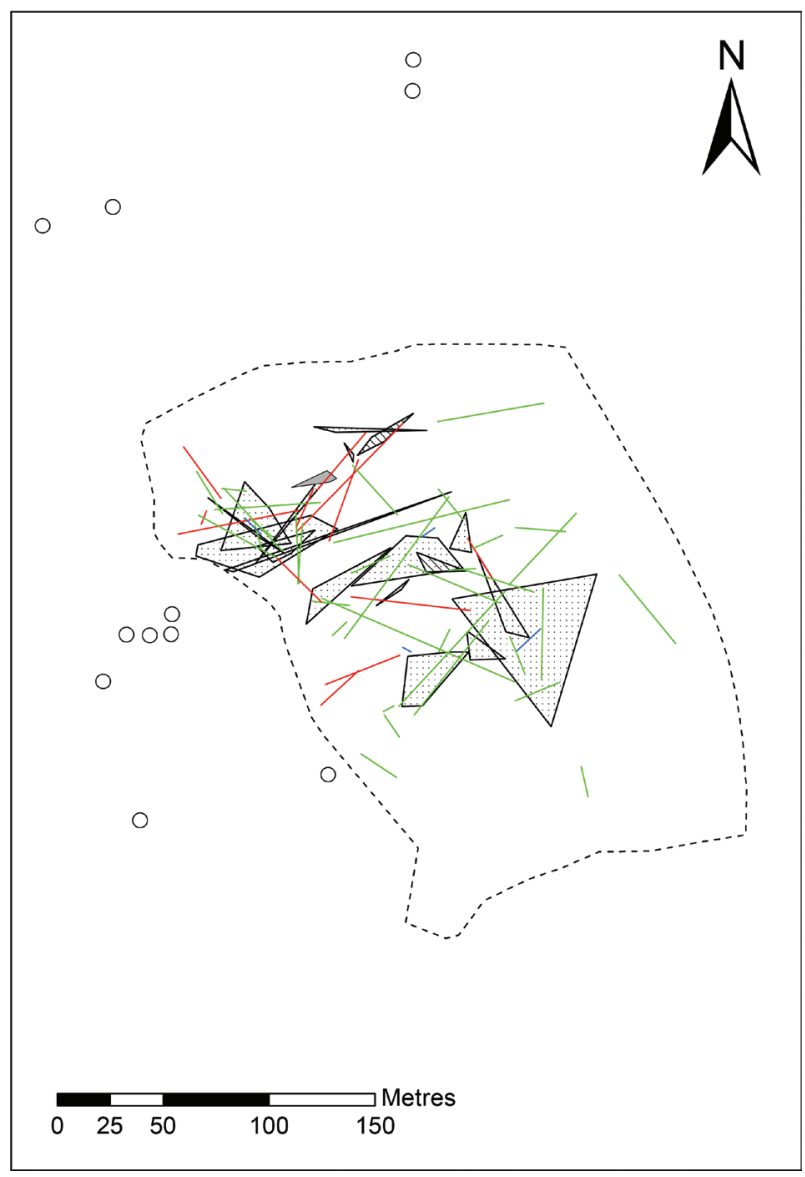

Figure 8. Home ranges and individual movements over all sampling periods in the Maurer Wald. The home range of individuals, captured three times or more, is represented by MCPs (Females: diagonal lines; Males: dotted; Unsexed: filled/grey). Distances between capture locations of individuals recaptured only once are represented by straight lines (Females: red; Males: green; Unsexed: blue). Circles denote breeding ponds.

er apparent survival could be caused by higher mortality, higher emigration, or both. Balogová et al. (2017) reported unequal apparent survival $\left(\varphi_{i}\right)$ estimates between the sexes for salamanders wintering in Slovakian subterranean sites and attributed this to a possible higher mortality of females due to their energetically demanding migrations to the breeding waters and also a lower ability to escape from predators during gravidity. In the Maurer Wald, we observed several cases of female fire salamanders that had been drowned by male frogs (Rana sp.), which were using the same ponds as breeding waters. Such an incident was described by Linnenbach (2000) from a population in southern Germany. Varying migration patterns and destinations of females, caused by annually changing breeding water availabilities in the Maurer Wald, might be another reason for the low annual apparent survival estimates. Leeb (2013) conducted a camera trap study in the Maurer Wald where he found no significant differences in the annual return rates to a hibernation site between the sexes; these results suggest no difference in mortality rate and therefore support variation in movement activity 
causing the low apparent survival estimate. Further evidence comes from capture-recapture data collected in the vicinity of the sampling area in the Maurer Wald. Many of the females only found a single time during our sampling occasions were found again outside our sampling area or sampling periods. Although these data were not included in our models, they support the hypothesis that movement activity, not mortality, was the main cause of the low apparent survival estimates.

The estimates for annual recapture probability fall within the range of the recapture rate estimates from other fire salamander populations in central Europe, which seem to strongly vary with sampling effort (cf. Schmidt et al. 2007 and Schmidt et al. 2014). Although generally low, for the Maurer Wald the estimates were around twice as high as those for Neuwaldegg. Our estimated values were probably also strongly influenced by the sampling sites' terrain. The site in the Maurer Wald was flatter, thus more easily observable and provided fewer hiding spots, which probably resulted in a higher detection rate. Balogová et al. (2017) reported similar results for two wintering sites with unequal observation possibilities. Another reason might be the different ways the two populations were sampled. For line transect sampling, as it was conducted in Neuwaldegg, the chance of individuals temporarily leaving the sampling area might be uniformly higher, lowering recapture probability. Such uniformity might also be a reason why goodness-of-fit-testing did not yield evidence for heterogeneity in recapture probability, which would have been caused by unequal temporary emigration.

Estimated population density in Neuwaldegg was more than twice as high as in the Maurer Wald. These results fall in line with our expectations and might be caused by different environmental conditions. Oak-hornbeam forests (Maurer Wald) are usually located in drier areas than beech forests (Neuwaldegg) (Ellenberg 1988). This dryness may limit the time the salamanders can spend on the surface feeding and also the available food. This is supported by Mayerhofer (2013), who found that females from Neuwaldegg had on average higher body condition index values than those from the Maurer Wald. The rising trend in net population size estimates might signal that the maximum population density, which the habitat in the Maurer Wald can support, is not yet reached. Salamandra salamandra had not been reported from the Maurer Wald until 1988 (Tiedemann 1990). The first documented sightings at this site date from 2006 (Gollmann 2006). Therefore, it is possible that the population, at the time of sampling, was still in the process of establishing. Grillitsch (1990) reported the occurrence of Hyla arborea in a pond close to the sampling area until 1980, while no occurrence of Hyla arborea was observed during our study. This implies that those ponds were less shaded in the past, and therefore less favourable for salamander larvae. Considering the relatively low overall recapture rate (320 captures; 217 individuals), a possible year-to-year rise in sampling intensity in the Maurer Wald might have also had an influence on the population size estimations and possibly caused the rise in estimated population size.

Most of the recaptured individuals in Neuwaldegg $(88 \%)$ and the Maurer Wald (78\%) were observed to have moved less than $50 \mathrm{~m}$ within the same year and therefore seemed rather sedentary. In the Kottenforst, however, around 25\% of salamanders of a pond-adapted subpopulation were reported to have covered distances that exceeded the span of the observed area in Maurer Wald (Hendrix et al. 2017). Based on the data we collected outside of the sampling plot in the Maurer Wald we found that five individuals previously encountered in the plot moved between 100 and 200 $\mathrm{m}$ and one individual even $500 \mathrm{~m}$ within a year. However, for conclusive results regarding total movement distances, probably larger areas need to be sampled consistently.

Estimated home ranges showed neither differences between sexes nor between sampling sites. On average (median: $115 \mathrm{~m}^{2}$; mean: $263 \mathrm{~m}^{2}$; range: 4-2329 $\mathrm{m}^{2}$ ) they were noticeably smaller than the home ranges reported by Schulte et al. (2007) (mean: $1295 \mathrm{~m}^{2}$; range: 659-2265 $\mathrm{m}^{2}$ ) or Hendrix et al. (2017) (mean: $3894 \mathrm{~m}^{2}$; 429-14594 $\mathrm{m}^{2}$ ), but larger than the results of earlier studies. Denoël (1996) reported sizes ranging from 5 to $255 \mathrm{~m}^{2}$ for a population in Belgium and Catenazzi (1998) sizes ranging from $<1$ to $131 \mathrm{~m}^{2}$ for a population in the Swiss Alps. All reported home ranges, however, seem to correlate with the size of the overall sampled areas in each study. The values presented in this study should be considered minimum home range sizes, as many contain only three capture points. Home range sizes might also strongly vary with the time of the year the sampling was conducted. For some populations of $S$. salamandra the winter and summer quarters lie at different locations (Feldmann 1987; Thiesmeier 2004). If sampling was done during the migrations to these locations, which take place during spring and autumn, home range estimates should be expected to be larger compared to sampling outside of these times.

Breeding in stagnant water bodies may be more common in fire salamanders than generally recognized, also in the western subspecies $S$. s. terrestris (Denoël and Winandy 2014; Arntzen and van Belkom 2020). A comparison of the well-studied situation in the Kottenforst with that in Vienna does not support generalisations about stream-breeding versus pond-breeding populations but suggests that local environmental conditions shape the variation in life history traits. Whereas food supply is low in forest ponds in western Germany (Weitere et al. 2004; Reinhardt et al. 2013), salamander larvae in some ponds in the Maurer Wald grew much faster than those in streams - at least in some years - due to a rich supply of plankton and hatching Rana tadpoles (Keckeis 2013; pers. obs.). In Neuwaldegg, the moister conditions in the beech forests seem to provide better habitats for the adult salamanders, as shown by higher body condition index values (Mayerhofer 2013) and population density (this study) than those obtained in the Maurer Wald.

In the Kottenforst, Hendrix et al. (2017) reported that the pond-adapted subpopulation showed greater moving 
distances and home range sizes as well as a higher variability in those parameters than the stream-adapted subpopulation. Our results partially coincide with these findings. Although the sampling area was smaller, the population in the Maurer Wald showed larger movement during the sampling periods. The home ranges, however, did not differ between sampling sites. It is likely that home ranges of salamanders exceed the limits of our sampling areas. From the topography of the landscape, it might be expected that stream breeding salamanders - in Neuwaldegg and similar sites - cover larger migration distances than those in the relatively confined area of the Maurer Wald, where a mass hibernation site was located (Leeb 2013; Leeb et al. 2013). To test this hypothesis, further studies at a larger spatial scale are needed.

\section{Acknowledgements}

We thank Walter Hödl for initiating our studies and providing logistic support. Eva Ringler helped during several phases of data analysis, which improved the study. The students of the field course "Populationsbiologie heimischer Amphibien" at the University of Vienna were an essential help for data collection. Capture and handling of salamanders were approved by the municipality of Vienna (permit MA 22 - 3726/2009). The quality of our presentation benefitted from thorough and attentive reviews. Open access funding provided by University of Vienna.

\section{References}

Akaike H (2011) Akaike's Information Criterion. In: Lovric M (Ed.) International Encyclopedia of Statistical Science. Springer, Berlin, Germany, 25 pp. https://doi.org/10.1007/978-3-642-04898-2_110

Anderson DR, Burnham KP (1999) Understanding information criteria for selection among capture-recapture or ring recovery models. Bird Study 46: 14-21. https://doi.org/10.1080/00063659909477227

Arntzen JW, Abrahams C, Meilink WRM, Iosif R, Zuiderwijk A (2017) Amphibian decline, pond loss and reduced population connectivity under agricultural intensification over a 38 year period. Biodiversity and Conservation 26: 1411-1430. https://doi.org/10.1007/s10531017-1307-y

Arntzen JW, van Belkom J (2020) 'Mainland-island' population structure of a terrestrial salamander in a forest-bocage landscape with little evidence for in situ ecological speciation. Scientific Reports 10: e1700. https://doi.org/10.1038/s41598-020-58551-0

Bailey LL, Nichols JD (2006) Capture-mark-recapture, removal sampling, and occupancy models. In: Dodd CK (Ed.) Amphibian ecology and conservation: a handbook of techniques. Oxford University Press, Oxford, 447-464.

Balogová M, Jelić D, Kyselová M, Uhrin M (2017) Subterranean systems provide a suitable overwintering habitat for Salamandra salamandra. International Journal of Speleology 46: 321-329. https:// doi.org/10.5038/1827-806X.46.3.2026

Balogová M, Kyselová M, Uhrin M (2016) Changes in dorsal spot pattern in adult Salamandra salamandra (Linnaeus, 1758). Herpetozoa
28: 167-171. https://www.zobodat.at/pdf/HER $28 \quad 3 \quad 4$ 0167-0171. pdf [Accessed 11 September 2020]

Bar-David S, Segev O, Peleg N, Hill N, Templeton AR, Schultz CB, Blaustein L (2007) Long-distance movements by fire salamanders (Salamandra infraimmaculata) and implications for habitat fragmentation. Israel Journal of Ecology \& Evolution 53: 143-159. https://doi.org/10.1080/15659801.2007.10639579

Bolger DT, Morrison TA, Vance B, Lee D, Farid H (2012) A computer-assisted system for photographic mark-recapture analysis. Methods in Ecology and Evolution 3: 813-822. https://doi.org/10.1111/ j.2041-210X.2012.00212.x

Bonato L, Fracasso G (2003) Movements, distribution pattern and density in a population of Salamandra atra aurorae (Caudata: Salamandridae). Amphibia-Reptilia 24: 251-260. https://doi. org/10.1163/156853803322440736

Bull JJ, Shine R (1979) Iteroparous animals that skip opportunities for reproduction. The American Naturalist 114: 296-303. https://doi. org/10.1086/283476

Burnham KP, Anderson DR (2002) Model selection and multimodel inference: A practical information-theoretic approach ( $2^{\text {nd }}$ ed. $)$. Springer, New York, 488 pp.

Caspers BA, Krause ET, Hendrix R, Kopp M, Rupp O, Rosentreter K, Steinfartz S (2014) The more the better - polyandry and genetic similarity are positively linked to reproductive success in a natural population of terrestrial salamanders (Salamandra salamandra). Molecular Ecology 23: 239-250. https://doi.org/10.1111/ mec. 12577

Catenazzi A (1998) Ecologie d'une population de Salamandre tachetée au Sud des Alpes. Master Thesis, Université de Neuchâtel, Neuchâtel, Switzerland. https://sites.google.com/site/acatenazzi/ ecologied $\% 27$ unepopulationdesalamandretache [Accessed 11 September 2020]

Cayuela H, Besnard A, Bonnaire E, Perret H, Rivoalen J, Miaud C, Joly P (2014) To breed or not to breed: past reproductive status and environmental cues drive current breeding decisions in a longlived amphibian. Oecologia 176: 107-116. https://doi.org/10.1007/ s00442-014-3003-X

Choquet R, Reboulet A-M, Pradel R, Gimenez O, Lebreton J-D (2004) M-SURGE: new software specifically designed for multistate capture-recapture models. Animal Biodiversity and Conservation 27: 207-215. https://www.raco.cat/index.php/ABC/article/view/57159 [Accessed 3 December 2020]

Cushman SA (2006) Effects of habitat loss and fragmentation on amphibians: a review and prospectus. Biological Conservation 128: 231-240. https://doi.org/10.1016/j.biocon.2005.09.031

Denoël M (1996) Phénologie et domaine vital de la salamandre terrestre Salamandra salamandra terrestris (Amphibia, Caudata) dans un bois du Pays de Herve (Belgique). Cahiers d'Ethologie 16: 291-306. http://hdl.handle.net/2268/3224 [Accessed 11 September 2020]

Denoël M, Winandy L (2014) Fire salamander (Salamandra salaman$d r a$ ) in Larzac plateau: low occurrence, pond-breeding and cohabitation of larvae with paedomorphic palmate newts (Lissotriton helveticus). Acta Herpetologica 9: 43-49.

Duellman WE, Trueb L (1994) Biology of Amphibians. Johns Hopkins University Press, Baltimore, 694 pp.

Efford MG (2020) openCR: Open population capture-recapture models. R package version 1.4.4. https://CRAN.R-project.org/package $=$ openCR/ [Accessed 3 December 2020] 
Ellenberg H (1988) Vegetation ecology of Central Europe. Cambridge University Press, Cambridge, 731 pp.

Feldmann R (1987) Überwinterung, Ortstreue und Lebensalter des Feuersalamanders, Salamandra salamandra terrestris. Schlußbericht einer Langzeituntersuchung. Jahrbuch für Feldherpetologie 1: 33-44.

Gimenez O, Cam E, Gaillard J-M (2018) Individual heterogeneity and capture-recapture models: what, why and how? Oikos 127: 664 686. https://doi.org/10.1111/oik.04532

Gollmann G (2006) Kartierung der Amphibienvorkommen im Natura 2000-Gebiet Liesing, Vienna, Austria: MA 22 - Umweltschutz, Stadt Wien.

Gopalaswamy AM, Royle JA, Hines JE, Singh P, Jathanna D, Kumar NS, Karanth KU (2012) Program SPACECAP: software for estimating animal density using spatially explicit capture-recapture models. Methods in Ecology and Evolution 3: 1067-1072. https://oi. org/10.1111/j.2041-210X.2012.00241.x

Grillitsch H (1990) Europäischer Laubfrosch. In: Tiedemann F (Ed.) Lurche und Kriechtiere Wiens. J \& V Edition Wien, Vienna, 80-86.

Griffiths RA, Sewell D, McCrea RS (2010) Dynamics of a declining amphibian metapopulation: Survival, dispersal and the impact of climate. Biological Conservation 143: 485-491. https://doi. org/10.1016/j.biocon.2009.11.017

Harper AC, Guynn Jr DC (1999) Factors affecting salamander density and distribution within four forest types in the Southern Appalachian Mountains. Forest Ecology and Management 114: 245-252. https:// doi.org/10.1016/S0378-1127(98)00355-7

Harper EB, Rittenhouse TAG, Semlitsch RD (2008) Demographic consequences of terrestrial habitat loss for pool-breeding amphibians: predicting extinction risks associated with inadequate size of buffer zones. Conservation Biology 22: 1205-1215. https://doi. org/10.1111/j.1523-1739.2008.01015.x

Heatwole H (1962) Environmental factors influencing local distribution and activity of the salamander, Plethodon cinereus. Ecology 43: 460-472. https://doi.org/10.2307/1933374

Hendrix R, Schmidt BR, Schaub M, Krause ET, Steinfartz S (2017) Differentiation of movement behaviour in an adaptively diverging salamander population. Molecular Ecology 26: 6400-6413. https:// doi.org/10.1111/mec.14345

Keckeis S (2013) Geometric morphometrics of body shape of Salamandra salamandra larvae from diverse water bodies. Master Thesis, University of Vienna, Vienna.

Klewen R (1985) Untersuchungen zur Ökologie und Populationsbiologie des Feuersalamanders (Salamandra salamandra terrestris Lacépède 1788) an einer isolierten Population im Kreis Paderborn. Abhandlungen aus dem Westfälischen Museum für Naturkunde 47: $1-51$.

Lebreton J-D, Burnham KP, Clobert J, Anderson DR (1992) Modeling survival and testing biological hypotheses using marked animals: a unified approach with case studies. Ecological Monographs 62: 67-118. https://doi.org/10.2307/2937171

Leeb C (2013) Mass hibernation and notes on winter activity of fire salamanders (Salamandra salamandra) in the Maurer Wald (Vienna, Austria). Master Thesis, University of Vienna, Vienna.

Leeb C, Hödl W, Ringler M (2013) A high-quality, self-assembled camera trapping system for the study of terrestrial poikilotherms tested on the Fire Salamander. Herpetozoa 25: 164-171. http:// www.zobodat.at/pdf/HER_25_3_4_0164-0171.pdf [Accessed 11 September 2020]
Linnenbach M (2000) Fehlpaarung zwischen Rana temporaria und Salamandra salamandra mit tödlichem Ausgang. Zeitschrift für Feldherpetologie 7: 224-225.

Lötters S, Wagner N, Albaladejo G, Böning P, Dalbeck L, Düssel H, Feldmeier S, Guschal M, Kirst K, Ohlhoff D, Preissler K, Reinhardt T, Schlüpmann M, Schulte U, Schulz V, Steinfartz S, Twietmeyer S, Veith M, Vences M, Wegge J (2020) The amphibian pathogen Batrachochytrium salamandrivorans in the hotspot of its European invasive range: past-present-future. Salamandra 56: 173-188. http://www.salamandra-journal.com/index.php/home/ contents/2020-vol-56/1979-loetters-s-n-wagner-g-albaladejo-pboening-l-dalbeck-h-duessel-s-feldmeier-m-guschal-k-kirst-d-ohlhoff-k-preissler-t-reinhardt-m-schluepmann-u-schulte-v-schulz-ssteinfartz-s-twietmeyer-m-veith-m-vences-j-wegge/file [Accessed 11 September 2020]

Manenti R, Conti A, Pennati R (2017) Fire salamander (Salamandra salamandra) males' activity during breeding season: effects of microhabitat features and body size. Acta Herpetologica 12: 29-36.

Martel A, Spitzen-van der Sluijs A, Blooi M, Bert W, Ducatelle R, Fisher MC, Woeltjes A, Bosman W, Chiers K, Bossuyt F, Pasmans F (2013) Batrachochytrium salamandrivorans sp. nov. causes lethal chytridiomycosis in amphibians. Proceedings of the National Academy of Sciences of the United States of America 110: 15325-15329. https://doi.org/10.1073/pnas.1307356110

Marvin GA (2001) Age, growth, and long-terms site fidelity in the terrestrial plethodontid salamander Plethodon kentucki. Copeia 2001: 108-117.https://doi.org/10.1643/0045-8511(2001)001[0108:AGAL TS]2.0.CO;2

Mayerhofer M (2013) Life-history variation in fire salamanders (Salamandra salamandra, Linnaeus, 1758) in the Vienna Woods. Master Thesis, University of Vienna, Vienna.

Muths E, Scherer RD, Pilliod DS (2011) Compensatory effects of recruitment and survival when amphibian populations are perturbed by disease. Journal of Applied Ecology 48: 873-879. https://doi. org/10.1111/j.1365-2664.2011.02005.x

Nöllert A, Nöllert C (1992) Die Amphibien Europas: Bestimmung, Gefährdung, Schutz. Kosmos Naturführer. Franckh-Kosmos, Stuttgart, $382 \mathrm{pp}$.

Oswald P, Tunnat BA, Hahn LG, Caspers BA (2020) There is no place like home: larval habitat type and size affect risk-taking behaviour in fire salamander larvae (Salamandra salamandra). Ethology 126: 914-921. https://doi.org/10.1111/eth.13070

Pollock KH (2000) Capture-recapture models. Journal of the American Statistical Association 95: 293-296. https://doi.org/10.1080/016214 59.2000.10473926

Powell RA (2000) Animal home ranges and territories and home range estimators. In: Boitani L, Fuller T (Eds) Research Techniques in Animal Ecology: Controversies and Consequences. Columbia University Press, New York, 65-110.

R Core Team (2020) R: a language and environment for statistical computing. http://www.r-project.org [Accessed 10 September 2020]

Rebelo R, Leclair MH (2003) Site tenacity in the terrestrial salamandrid Salamandra salamandra. Journal of Herpetology 37: 440-445. https://doi.org/10.1670/0022-1511(2003)037[0440:STI TTS]2.0.CO;2

Reinhardt T, Steinfartz S, Paetzold A, Weitere M (2013) Linking the evolution of habitat choice to ecosystem functioning: direct and indirect effects of pond-reproducing fire salamanders on aquatic-ter- 
restrial subsidies. Oecologia 173: 281-291. https://doi.org/10.1007/ s00442-013-2592-0

Rodgers AR, Kie JG, Wright D, Beyer HL, Carr AP (2015) HRT: Home range tools for ArcGIS. http://flash.lakeheadu.ca/ arodgers/hre/ [Accessed 11 September 2020]

Sandercock BK (2006) Estimation of demographic parameters from live-encounter data: a summary review. Journal of Wildlife Management 70: 1504-1520. https://doi.org/10.2193/0022-541X(2006)70[ 1504:EODPFL]2.0.CO;2

Schmidt BR, Feldmann R, Schaub M (2005) Demographic processes underlying population growth and decline in Salamandra salamandra. Conservation Biology 19: 1149-1156. https://doi.org/10.1111/ j.1523-1739.2005.00164.x

Schmidt BR, Itin E, Schaub M (2014) Seasonal and annual survival of the salamander Salamandra salamandra salamandra. Journal of Herpetology 48: 20-23. https://doi.org/10.1670/12-056

Schmidt BR, Schaub M, Steinfartz S (2007) Apparent survival of the salamander Salamandra salamandra is low because of high migratory activity. Frontiers in Zoology 4: 1-19. https://doi.org/10.1186/17429994-4-19

Schulte U, Küsters D, Steinfartz S (2007) A PIT tag based analysis of annual movement patterns of adult fire salamanders (Salamandra salamandra) in a Middle European habitat. Amphibia-Reptilia 28: 531-536. https://doi.org/10.1163/156853807782152543

Schwarz CJ, Arnason AN (1996) A general methodology for the analysis of capture-recapture experiments in open populations. Biometrics 52: 860-873. https://doi.org/10.2307/2533048
Steinfartz S, Weitere M, Tautz D (2007) Tracing the first step to speciation: ecological and genetic differentiation of a salamander population in a small forest. Molecular Ecology 16: 4550-4561. https://doi. org/10.1111/j.1365-294X.2007.03490.x

Sztatecsny M, Gollmann G, Leeb C, Philippi D (2014) Aus Tümpel, Teich und Bach: Vorkommen und Verbreitung von Amphibien in den Wäldern des Biosphärenparks Wienerwald. Wissenschaftliche Mitteilungen des Niederösterreichischen Landesmuseums 25: 453-474.

Thiesmeier B (2004) Der Feuersalamander. Zeitschrift für Feldherpetologie. Supplement (Vol. 4). Laurenti Verlag, Bielefeld, 192 pp.

Tiedemann F (1990) Feuersalamander, Gefleckter Feuersalamander Salamandra salamandra salamandra (Linnaeus, 1758). In: Tiedemann F (Ed.) Lurche und Kriechtiere Wiens. J \& V Edition Wien, Vienna, 38-41.

Weitere M, Tautz D, Neumann D, Steinfartz S (2004) Adaptive divergence vs. environmental plasticity: tracing local genetic adaptation of metamorphosis traits in salamanders. Molecular Ecology 13: 1665-1677. https://doi.org/10.1111/j.1365-294X.2004.02155.x

White GC (2020) MARK. http://phidot.org/software/mark/index.html [Accessed 11 September 2020]

White GC, Burnham KP (1999) Program MARK: survival estimation from populations of marked animals. Bird Study 46: 120-139. https://doi.org/10.1080/00063659909477239

Zutz C (2012) Genetic diversity under the strain of habitat fragmentation: a population genetic analysis of two Salamandra salamandra populations from the Vienna Woods. Master Thesis, University of Vienna, Vienna. 